\title{
THE SISYPHEAN OPENING OF THE FIRST SOVIET CANTEENS IN THE URALS: SUCCESSES AND FAILURES (1918-1925)*
}

\author{
François-Xavier Nérard \\ Université Paris 1 Panthéon-Sorbonne, CRHS - SIRICE, \\ Paris, France
}

The development of catering facilities in the Urals after the Revolution is a good vantage point to observe Soviet power in practice. Ideology was certainly not absent from the Bolshevik project: canteens were to play a major role in the new society. More particularly, they were to provide the liberation of women. However, their role should not be overestimated. It is often limited to the first lines of official discourses and documents. This article looks at practices of rule. The analysis is based on documents from regional archives (party and state archives) on the establishment of new catering facilities and the acquisition of the necessary resources. The article also considers the attitude of ordinary citizens to the new canteens, their preferences in choosing a place to eat, and society's reaction to the Bolshevik policy of organising everyday life. It is possible to single out two attempts to establish a system of public canteens: immediately after the Bolshevik victory and at the beginning of the New Economic Policy. Both failed. Canteens and the communal way of dining they provided were not able to attract enough clients and customers. As in the majority of other European countries, workers and city dwellers preferred to eat at home rather than in cafeterias. The only thing that could attract them to such places was beer. Therefore, the canteens of the NEP were far from the initial ideological project. Activists in cooperatives and officials in the administration tried, however, to build and develop new catering facilities. The minutes of meetings and conferences demonstrate the real reasons behind such activities.

Keywords: public catering; factory canteens; establishment of Soviet power in the Urals.

Развитие системы общественного питания после Октябрьской революции является интересным объектом, позволяющим проследить становление советской власти и ее практик. Даже в повседневной культуре идеология задавала основной тренд развития общественных институ-

* Citation: Nérard, F.-X. (2017). The Sisyphean Opening of the First Soviet Canteens in the Urals: Successes and Failures (1918-1925). In Quaestio Rossica, Vol. 5, № 4, p. 1063-1072. DOI 10.15826/qr.2017.4.267.

Цитирование: Nérard F.-X. The Sisyphean Opening of the First Soviet Canteens in the Urals: Successes and Failures (1918-1925) // Quaestio Rossica. Vol. 5. 2017. № 4. P. 1063-1072. DOI 10.15826/qr.2017.4.267.

(C) Nérard F.-X., 2017

Quaestio Rossica • Vol. 5 • 2017 • № 4, p. 1063-1072 
тов. Общественные столовые, например, должны были играть ключевую роль в коммунистическом преобразования быта и раскрепощении женщин. Однако, по мнению автора, нельзя преувеличивать эту роль. После принятия соответствующих декретов и решений партийные деятели и советские чиновники обратились к их реализации. В статье анализируются советские управленческие практики. Источниковую базу исследования составили сведения из архивных материалов об открытии новых столовых, обретении необходимых ресурсов. Также анализируется, каким было отношение граждан к новым столовым, каковы были их предпочтения в налаживании питания (домашнего или общественного), как общество реагировало на политику большевиков в организации повседневного быта. Можно выделить две попытки создания сети общественных столовых: сразу после революции и победы большевиков, а также в начале НЭПа. Каждая из них закончилась провалом. Как и во многих европейских странах, рабочие и горожане предпочитали обедать дома. Только продажа пива помогала привлечь их в новые заведения. Поэтому столовые времен НЭПа оказались далеки от идеологического проекта, с которого все началось. При этом кооператоры и чиновники открывали новые заведения и старались развивать их. Протоколы собраний и заседаний раскрывают истинные причины такой деятельности.

Ключевые слова: общественное питание; заводские столовые; становление советской власти на Урале.

Ever tried. Ever failed. No matter. Try again. Fail again. Fail better. Samuel Beckett. Worstward Ho. 1983

At the end of 1925, the head of Sverdlovsk central workers' cooperative assessed the work of the collective catering system in his region: "Working in the collective catering system, we are still at school. We must accumulate knowledge in that field, in order to, circumstances permitting, develop and expand it” [ЦДООСО. Ф. 6. Оп. 1. Д. 535. Л. 47 об.]. Such appraisal may sound somehow surprising as, at that time, it has been already almost eight years since the first Soviet canteens opened in the Urals. The history of the creation of cafeterias and canteens in the Urals region, and to a lesser extent, in the whole country, seems indeed to be a history of repeated failures and repeated attempts. The region, an important industrial territory since the eighteenth century, is an interesting vantage point. Workers, a key category of potential users of canteens, were numerous, but the structures of the region are very different from other industrial and urban centers as Petersburg or Moscow. There, as shown by Mauricio Borrero or Mary McAuley, if meeting with difficulties, the offer of collective catering reached a significant level rapidly thanks to already existing infrastructure. It was far more unspecified in the Urals, where the Bolsheviks had to build a system out of almost nothing. 
Food provisioning was a major problem of Russia during the war and the civil war. The food requisitions and the violence linked to it led to what is used to be called the "food dictatorship" [Lih, p. 139-166]. But whereas this "input" is relatively well known, the output phase is much less studied. Canteens were one of the tools the Bolsheviks chose to use. They fitted well in their ideological project, trying to build a new society where the collective was set to play a crucial role. For all that, they were not a Bolshevik invention. Lenin himself, while recognizing their importance, linked them to the "acrobatics of bourgeois charity" [Ленин, с. 24]. They indeed corresponded to the spirit of times. The First World War period, elsewhere in Europe, think about France and Britain for example, also corresponded to a rise in the use of canteens, still in its early stages in the former period [Bouchet et al.].

This paper aims at mapping out the role of ideology and pragmatism in the actions of the Soviet regime in its first months. Canteens are actually a good study field to understand these dimensions. Were they a purely ideological project doomed to fail? Whereas Soviet regime is more than often thought through the prism of ideology, we may need to proceed to a kind of disenchantment of the Soviet experiment. I will try to explain why canteens regularly failed, in spite of the stubbornness of the Bolsheviks, trying ever and ever again to develop obchepit. What do these first Bolshevik canteens tell us about the new authorities, their ideas and practices? What were the role and the importance of the canteens in the alimentation of the population? What about their efficiency?

\section{Ever-Rising Canteens}

The process of opening canteens in the Urals region, and to a large extent in the whole Soviet Union, is not a linear one. There are multiple attempts, that ended generally in failure and every few months (1918, 1919, 1921 and 1923), authorities claim to lay the "real" foundations of the right system of collective catering "one of the most important tasks of the construction of the socialist society" [ГАСО. Ф. 10. ОП. 1. Д. 119. Л. 190].

The first failed attempts to create canteens/cafeterias in Ekaterinburg were linked as elsewhere with philanthropy and had a strong moral and educational dimension: they were to feed the poor people of the city. On April 24, 1881, the city Duma of Ekaterinburg decided to open a "cheap and free cafeteria for the poor" and to name it after the deceased emperor Alexander II, killed a few days before (on March 1st) in Saint Petersburg. The project was really detailed. Meals were to be composed of two dishes and bread. The canteen was supposed to serve a 100 clients (among whose 50 were to be fed for free). The budget of the canteen was partly sponsored by the city Duma but mostly funded by private donations. More than 8000 rubles were collected [ГАСО. Ф. 62. ОП. 1. Д. 101. Л. 63].

Two years later in March 1883, the authorities dropped the project for different reasons. They referred mainly to administrative difficulties but, 


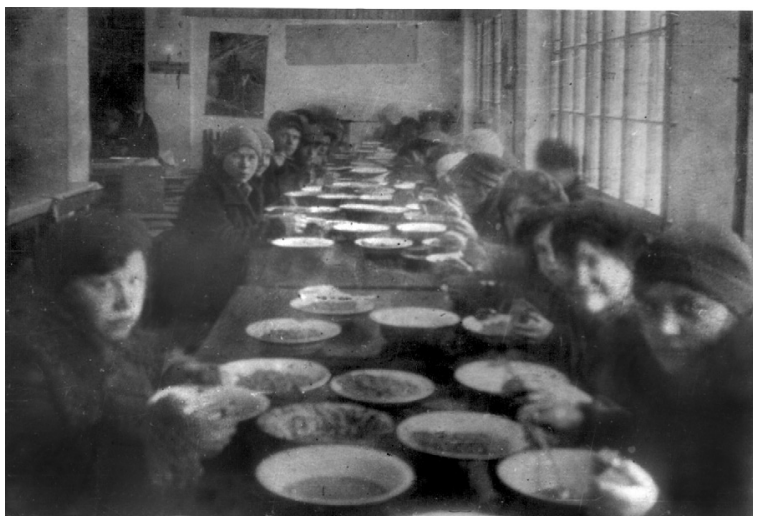

Uralmash (Sverdlovsk). Canteen. 1930s.

The Archive of the Museum of Uralmash

most probably, they measured the risks of failure. There seemed to be no demand for such a place. The Duma councilors referred to the experience of the Active State Councilor Miller, who opened a cheap canteen on the same philanthropic basis. It obtained dismal results because of the "absence of voluntary to eat in the canteen not only for a cheap fare but also for free" [ГАСО. Ф. 62. Оп. 1. Д. 101. Л. 45].

Due to these early failures, canteens were an almost total novelty in the region at the time the Bolsheviks tried to open some upon instructions of the "central authorities", following, to use the words of Vladimir Galin-Umanski, charged with this task, the experience of the "Capital of the Red North, where almost all the revolutionary population is attached to city canteens" [ГАСО. Ф. Р-183. Оп. 1. Д. 46. Л. 15]. Indeed, this was an early preoccupation of the new authorities. As soon as October 28, 1917, a few days after the revolution, a decree of the people's commissar council on food supply mentioned the transformation of private restaurants into canteens as a solution to these problems ${ }^{1}$.

A communist canteen (i. e. a canteen open only to members of the party) was opened in Perm by the Urals regional committee of the Party. It worked at least from Octobre 1918 until the fall of the city to the White insurgents at the end of December [ЦДООСО. Ф. 4. Оп. 1. Д. 30]. In liberated Ekaterinburg (on July 15, 1919), the Bolsheviks tried very quickly to develop collective catering and met already a rapid failure. As early as Octobre 1919, a committee for collective catering was organized inside the Guardroom (the regional branch of the Narkomprod, the people's commissariat for food supply). That same month, five canteens were opened in the city. In December, confronted by unsuccess or lack of food, 5 of the 8 canteens were ordered to close for dinner and their customers were to be concentrated in the 3 still opened [ГАСО. Ф. Р-183. Оп. 1. Д. 39. Л. 54; Д. 46. Л. 6].

The new bolshevik canteens fitted themselves partly in the old charity pattern: they targeted a large part of the population "hospitals, refugees due to the civil war, prisoners and concentration camps, nurseries and asylums." Children were also an important group. But they also introduced a new public for the canteens, the workers, bringing in the Urals a practice well-known elsewhere in the industrial world. In February 1920, "due to the food crisis," factories and mines from Lys'va, Kyselovskye mines 
or Nijni Tagil, for example, were to open new canteens [ГАСО. Ф. P-10. Оп. 1. Д. 43. Л. 67]. The task was more complicated than they fought.

In front of the worsening food crisis, turning into famine, the authorities tried constantly to reorganize the supply system, and, therefore, canteens. Tens of detailed instructions were issued, describing even the role of the cook in 12 points [ГАСО. Ф. Р-10. ОП. 1. Д. 121. Л. 36a]. Administrative structures changed: canteens became part of Potrebkommuna (consumer's commune), the new central organization responsible for supply, a result of the merging of the food supply committee and cooperatives. The system was still, however, fragile and the cafeterias were described as chaotic, inefficient, overstaffed (There were 1312 people working at the Potrebkommuna in 1921) sometimes later [ЦДООСО. Ф. 225. Оп. 1. Д. 469. Л. 21].

With the decree of April 7, 1921, on consumer cooperation, the launching NEP and the improvement of the food situation in the region, Bolsheviks abandoned definitively the charity model: free canteens stopped existing, and canteens became places where you had to pay to eat. From 22 canteens working in Ekaterinburg in 1921, there were only 7 left in 1923 [Там же. Л. 83-85]. The sector of alimentation of the Potrebkommuna considered that it had to rebuild from scratch a more efficient system. The question of the public was once more central: who were to be the clients of these canteens? Workers? A larger part of the population?

The question was important as canteens were opened mainly, if not exclusively, in the center of Ekaterinburg. Workers districts were largely ignored and the opening of cafeterias in these zones was considered as "a new phenomenon, undoubtedly risky and that makes a very cautious approach a necessity” [ЦДООСО. Ф. 76. Инв. 1. Д. 710. Л. 87 об.]. In a report, the direction of the Potrebkommuna was therefore forced to note sadly that "to talk seriously, in the current situation, of the existence of a mass proletarian collective alimentation in Ekaterinburg is impossible” [ЦДООСО. Ф. 225. Оп. 1. Д. 469. Л. 92].

At the end of 1925. 12 canteens were working in the city of Ekaterinburg (among them 2 buffets in the train station). The authorities had, however, to admit their relative failure considering that they are still "at school." The main problem remained the unwillingness of workers to go to the canteens even if as in Verkh-Iset "the canteen is clean and conformable, the building is nice. There are some newspapers, lunches are good and substantial" [ГАСО. Ф. Р-318. Оп. 1. Д. 64. Л. 72].

\section{Resisting the Canteens}

The resistance to the canteens is a well-known phenomenon in Western Europe where canteens were mainly open by owners of factories in order to control workers and make their work more efficient [Gacon, p. 34-42]. Nowhere, canteens were met with fervor by workers. Historian Martin Bruegel speaks truly of a "contested territory" [Bruegel, p. 188]. Part of the explanations of the repeated failures of the Urals canteens have to be found 
in such structural explanations, others are linked with more specific regional peculiarities.

The main enemy of the canteens were not, as often thought and told, the restaurants and the cafés (that were closed before the NEP). The home was the real place contending with the collective facilities, in Soviet Union as elsewhere [Scholliers, p. 114]. Due to low female employment, the food was prepared by women for the men who worked. Clients of canteens were therefore mostly people who did not have a "home": single men (or women) or guests of the city. Family members were very rare in the dining rooms.

In these conditions, even cheap lunches, as noticed in a 1925 report, were not profitable to workers whereas they jeopardized the economical balance of the cafeterias. The cost of a lunch in a worker's canteen was about 25 kopecks whereas it was of 40 in Central City ones, where everyone could go. With a worker middle wage of 40 to 50 rubles a month, it was far too expensive for the clients, even if already loss-making for the canteens themselves. "As bad as their lodging conditions may be, workers and employees try to cook at home, and try to use at the maximum every kopeck of their pay and free workforce" [ЦДООСО. Ф. 6. Оп. 1. Д. 535. Л. 47]. There is a sort of rationalization of the use of products by workers family. Firewood is therefore used for cooking and not only for heating the rooms.

"Food cooked at home, clothes, shoes - this is the work of the women, who have no more interesting and efficient work: this is actually a complementary salary. Everything that she should pay to others, she's doing by herself and, this way, saves money and products, raises the purchasing power of her husband's salary" [Там же].

This "home" model was at the core of the Urals industrial life. Rather than organizing canteens, employers were for a long time organizing direct food distribution. It was called the proviant, well before the revolution. By the way after the revolution, the Soviet authorities carried on with such practices of direct food distribution. It was made even easier by the fact that often the Urals worker "is living in a room not in a flat, with the possibility to use the kitchen, or even more often in his own house with a garden, he has a cow, a small meadow, a piece of arable land, etc." [ЦДООСО. Ф. 225. Оп. 1. Д. 469. Л. 95].

Reluctance to the use of canteens in the West was also linked with the refusal of employers' control over lunch time. Workers tried to preserve solidarity and uncontrolled discussions during lunch time far from the employers' ears. Incidentally, workers tried to avoid paternalistic and moral discourses. The failure of the 1881 canteen may probably partly explained by its strong moral dimension. "Clients" of the canteen were not supposed to beg (at the risk of losing the right of dining), they were not allowed inside the canteen if drunk, and were asked to behave themselves properly or to risk being expelled ("the guests must behave quietly and properly, without having loud, and even more indecent conversations" [ГАСО. Ф. 62. Оп. 1. Д. 101. Л. 13]). In the project of Soviet canteens, education and kulturnost were also important. In Perm, in 1918, communist bosses ordered 10 posters for their canteen with the slogan: "Comrades, respect order and cleanli- 
ness!” [ЦДООСО. Ф. 4. Оп. 1. Д. 30. Л. 17]. Even if the reality was far from that and dirtiness and noise were the rule, the perspective of being submitted to propaganda may have turned some people away.

Finally, the poor conditions of the stolovye were a major drawback, as testifies F. Galenychev, a future cook at the Stalingrad tractor factory, then (in 1921) working in one of the 130 canteens of his Moscow district: "The lunches served were awful. When a wagon of potatoes, dirty, frozen, was arriving, the potatoes were broken to pieces and cook that way, even not washed up. When nobody stole them" [Ильин, с. 399].

Overcoming these resistances was possible only under very specific and harsh conditions. In the 1920s as in the 1930s, it was the famine and the hunger. Figures are indeed impressive: Up to 20,000 meals a day were then served in 22 free canteens, at the district (uezd) level, there were 60 canteens, serving more than 57,000 people as of April 1921 [ГАСО. Ф. Р-62. Оп. 1. Д. 77. Л. 5]. Anyway, the end of the food provisioning difficulties had a very simple consequence a high drop of frequentation of the canteens. During high times of shortages, in 1921-22, up to $40-45 \%$ of families in main cities of Russia had, at least partially, some food outside of home, but fell to less than $1 \%$ after 1924 [Состояние питания, с. 33]! In Ekaterinburg, unfortunately we don't have so precise statistics but, for sure, the trend was the same as in the whole country.

\section{Necessity or superfluousness?}

Even if they did not meet their objectives, some canteens were yet working in the Urals. They fed thousands of people. "During the hard times of the food provisioning crisis, made even worse by the famine of 1921" was "to give workers and employees the unique possibility of a hot meal" [ЦДООСО. Ф. 225. Оп. 1. Д. 469. Л. 83]. This is far from negligible. That leads us not to be overwhelmed by the negative tone of sources on canteens (a very typical Soviet inclination, incidentally) and to pay attention to several important points.

First of all, the proactive and yet improvised attitude of the Bolsheviks in organizing collective catering is remarkable. In even dire conditions, they paid a real attention to the canteens. They used all existing resources up to, for example, confiscated objects of the fleeing bourgeoisie: big samovars in Ekaterinburg (the big ones, the smaller ones were to be transmitted to the city society of consumers [ГАСО. Ф. Р-183. Оп. 1. Д. 39. Л. 28]), a meat grinder of a former café called "Colibri” in Perm [ЦДООСО. Ф. 4. Оп. 1. Д. 30. Л. 69]. Part of state - controlled resources were also allocated to collective canteen: plates, spoons and professional clothes, but also food. Canteens were, however, only part of the distribution programs of the Bolsheviks, but direct food provisioning was still carried out. For example, in November 1919 out of 20 wagons of vegetables received by the regional food supply committee, only 1 was attributed to the sector of collective catering [ЦДООСО. Ф. 183. Оп. 1. Д. 39. Л. 37]. 
Buildings were in great need: the cinema Kolisei, the oldest of the city, was used partly for this aim [ЦДООСО. Ф. 183. Оп. 1. Д. 46. Л. 10]. Collective catering officials also tried to find people to make the canteen work and it was a major problem as most of the qualified workers had fled the cities. For the newly opened canteens in Ekaterinburg during the fall 1919, the sector of collective catering asked the party district committee to send them a "trained worker, familiar with the questions of collective catering." They also turn to the zhenotdel, the women section of the party, for control personal [Там же. Д. 39. Л. 21 об.].

What was really served in Soviet canteens varied strongly over time. Norms of food for December 1920 were poor. After the NEP had begun, things changed deeply. The canteens were organized into two main types: canteens for workers and employees, canteens opened to everyone. A survival of the charity system may be, in addition, found in Ekaterinburg, where a canteen was open at the Labour exchange for a few weeks in 1923. An average 275 unemployed people a day were served a two-meal lunch with 400 grams of bread and a 100 grams of meat. But it happened to be too expensive and the canteen was in the end closed [ЦДООСО. Ф. 225. Оп. 1. Д. 469. Л. 85].

Three canteens were reserved for workers and employees, proposing food at a low price. Only one was a real "workers" canteen. It was opened in August of 1922 in Verkh-Iset Factory, some two kilometers east of the city. This canteen, however, had very poor results, with an average of a mere 25 meals a day (17,407 clients on 9 months, and 6173 meals) [Там же, с. 86].

Four canteens in the city at the beginning of January 1924 were open to everybody. More expensive, they were sources of profits. But even if called "canteens," they were almost restaurants and have a very few in common with the other canteens. The best one was the Stolovaya ${ }^{\circ} 3$ at the crossing of Lenin and Tolmatchev streets, open 6 days a week from 2 pm to 2 am. On evenings "a trio of musicians is playing, and there is a billiard hall with three billiards" [Там же, с. 87].

When having a closer look at the statistics of these canteens, there's one feature that strikes particularly in all establishments regardless of their type and location (factories or central districts): a huge difference between the number of meals served and the number of clients. For example, the canteen $\mathrm{n}^{\circ} 2$, over 260 days of work, welcomed 62,618 clients but served only 24,537 meals [Ibid., p. 86]. The explanation is simple: far from the expected place of education or of the liberation of women, canteens become a place to drink! People came there and bought beer even if the sale of beer is limited to two bottles a person. Here is an abstract from the local newspaper Urals worker from Nov. 19, 1924. Its title is already sufficiently significant "On the payday at Verkh-Iset factory" "In the worker's canteen, all hell is let loose, there's no place to have lunch, all the seats are occupied by 'people with a bottle' [ГАСО. Ф. Р-318. Оп. 1. Д. 64. Л. 60].

Canteens and cafeterias are a very good vantage point to observe the Soviet power in practice and the way ideology is turned into reality. Deal- 
ing with an awkward situation on the food front, Bolsheviks turned to an idea they've been promoting: the development of collective catering. This ideological choice proved almost impossible to implement efficiently. The Russian society was resilient. When they had the choice, workers and city dwellers ate at home. Canteens worked with difficulties during the years of hunger, but never succeeded in becoming an essential part in the life of the Soviet citizens. Soviet managers and administrators tried, however, their best to organize what they thought were the cells of the communal life. Ironically enough, during the NEP times, the canteens were accused of becoming a Nepman nest! Cooperatives had to assure the authorities that 'the majority of clients in all the canteens of the potrebkommuna are without any doubt of proletarian origins' [ЦДООСО. Ф. 225. Оп. 1. Д. 469. Л. 95]. A few months after the famine, they had once again to show their necessity. Actually, most of them lost their clients. Selling beer was their only option to make a minimum amount of money. That's with the huge upheavals of the industrialization [Nérard] that collective catering will become an almost definitive feature of everyday life in the Urals.

\section{Список литературы}

ГАСО. Ф. 10, 62, 183, 318.

Ильин Я.Н. Люди сталинградского тракторного. М. : История заводов, 1933. 463 с.

Ленин В. И. Великий почин // Ленин В. И. Полн. собр. соч.: в 55 т. 5-е изд. М. : Политиздат, 1967-1981. Т. 39. 1969. С. 1-29.

О расширении прав городских самоуправлений в продовольственном деле: декрет Совета Народных Комиссаров от 28 октября 1917 г. // Собрание узаконений и распоряжений правительства за 1917-1918 гг. М. : Управление делами Совнаркома CCCP, 1942. C. 8-9. URL: http://istmat.info/node/27754 (дата обращения: 10.11.2016).

Состояние питания городского населения СССР в 1925/26 сельскохозяйственном году (по предварительным данным обследований питания городского населения, произведенных Отделом Статистики Потребления Ц. С. У. в октябре 1925 года и феврале 1926 года) // Труды Центрального статистического управления. Т. 30 . Вып. 5. М. : Тип. «Мосполиграф», 1927. 95 с. URL: http://istmat.info/node/28351 (дата обращения: 10.11.2016).

ЦДООСО. Ф. 4, 6, 183, 225.

Borrero M. Hungry Moscow : Scarcity and Urban Society in the Russian Civil War, 1917-1921. N. Y. : Peter Lang, 2003. 228 p.

Bouchet T., Gacon S., Jarrige F., Nérard F.-X., Vigna X. La gamelle et l'outil: manger au travail en France et en Europe de la fin du XVIIIe siècle à nos jours. Nancy: Arbre bleu éd., 2016. 367 p.

Bruegel M. Le repas à l'usine: industrialisation, nutrition et alimentation populaire // Revue d'histoire moderne et contemporaine. T. 51. No. 3. 2004. P. 183-198.

Gacon S. Cantines et alimentation au travail : Une approche comparée, du milieu du XIX e siècle à nos jours // Le mouvement social. Vol. 247. 2014. No. 2. P. 3-25.

Lih L.T. Bread and Authority in Russia, 1914-1921. Berkeley : Univ. of California Press, 1990.303 p.

McAuley M. Bread and Justice : State and Society in Petrograd, 1917-1922. Oxford : Oxford Univ. Press, 1991. 461 p.

Nérard F.-X. Nourrir les constructeurs du socialisme : Cantines et question alimentaire dans l'URSS des premiers plans quinquennaux (1928-1935) // Le Mouvement Social. Vol. 247. 2014. No. 2. P. 85-103. 
Scholliers $P$. Le temps consacré à l'alimentation par les familles ouvrières en Europe aux XIXe et XXe siècles // Le temps de manger : Alimentation, emploi du temps et rythmes sociaux / ed. M. Aymard, C. Grignon, F. Sabban. Paris : MSH/INRA, 1994. P. 111-137.

\section{References}

Borrero, M. (2003). Hungry Moscow: Scarcity and Urban Society in the Russian Civil War, 1917-1921. N. Y., Peter Lang. 228 p.

Bouchet, T., Gacon, S., Jarrige, F., Nérard, F.-X., Vigna, X. (2016). La gamelle et l'outil: manger au travail en France et en Europe de la fin du XVIIIe siècle à nos jours. Nancy, Arbre bleu éditions. 367 p.

Bruegel, M. (2004). Le repas à l'usine: industrialisation, nutrition et alimentation populaire. In Revue d'histoire moderne et contemporaine. T. 51, No. 3, pp. 183-198.

Gacon, S. (2014). Cantines et alimentation au travail: Une approche comparée, du milieu du XIX e siècle à nos jours. In Le mouvement social. Vol. 247. No. 2, pp. 3-25.

GASO [State Archives for Sverdlovsk Region]. Stock. 10, 62, 183, 318.

Il'in, Ya. N. (1933). Lyudi stalingradskogo traktornogo [People of the Stalingrad Tractor Plant]. Moscow, Istoriya zavodov. $463 \mathrm{p}$.

Lenin, V. I. (1969). Velikii pochin [The Great Beginning]. In Lenin, V. I. Polnoe sobranie sochinenii v 55 t. Ed. 5. Moscow, Politizdat. Vol. 39, pp. 1-29.

Lih, L. T. (1990). Bread and Authority in Russia, 1914-1921. Berkeley, Univ. of California Press, 1990. 303 p.

McAuley, M. (1991). Bread and Justice: State and Society in Petrograd, 1917-1922. Oxford, Oxford Univ. Press. $461 \mathrm{p}$.

Nérard, F.-X. (2014). Nourrir les constructeurs du socialisme. Cantines et question alimentaire dans l'URSS des premiers plans quinquennaux (1928-1935). In Le Mouvement Social. Vol. 247. No. 2, pp. 85-103.

O rasshirenii prav gorodskikh samoupravlenii v prodovol'stvennom dele: dekret Soveta Narodnykh Komissarov ot 28 oktyabrya 1917 g. [On the Expansion of Rights of Municipalities in Catering Activities]. (1942). In Sobranie uzakonenii i rasporyazhenii pravitel'stva za 1917-1918 gg. Moscow, Upravlenie delami Sovnarkoma SSSR, pp. 8-9. URL: http://istmat.info/node/27754 (mode of access: 10.11.2016).

Scholliers, P. (1994). Le temps consacré à l'alimentation par les familles ouvrières en Europe aux XIXe et XXe siècles. In Aymard, M., Grignon, C., Sabban, F. (Eds.). Le temps de manger. Alimentation, emploi du temps et rythmes sociaux. Paris, MSH/INRA, pp. 111-137.

Sostoyanie pitaniya gorodskogo naseleniya SSSR v 1925/26 sel'skokhozyaistvennom godu (po predvaritel'nym dannym obsledovanii pitaniya gorodskogo naseleniya, proizvedennykh Otdelom Statistiki Potrebleniya Ts. S. U. v oktyabre 1925 goda i fevrale 1926 goda) [The State of USSR Urban Population Catering in the 1925/1926 Agrarian Year (According to the Preliminary Data of the Examination of Urban Population Catering Collected by the Department of Statistics)]. (1927). In Trudy Tsentral'nogo statisticheskogo upravleniya. Vol. 30. Iss. 5. Moscow, Tipografiya "Mospoligraf". 95 p. URL: http://istmat.info/ node/28351 (mode of access: 10.11.2016).

TsDOOSO [Centre for the Documentation of the Social Organisations of Sverdlovsk Region]. Stock. 4, 6, 183, 225. 